\title{
A FAILURE REVISITED: THE FIRST FINNISH COMPUTER CONSTRUCTION PROJECT
} The establishing of a national computing center in Finland

\author{
Petri Paju \\ Cultural History, University of Turku, 20014 Finland; petpaju@utu.fi
}

Abstract: In this article, the first Finnish computer construction, previously claimed to have produced only an out-dated machine, is studied as an integral part of an attempt to establish a national computer center in Finland. I argue that the aim of the Finnish Committee for Mathematical Machines (1954-1960) was more similar to its Swedish and Danish counterparts than has been recognized, even though the Finnish Committee decided to duplicate a German Gla computer in 1954. The similarity with Sweden and Denmark arises from the aim of the Committee to establish a national computing center, like the ones in Stockholm and Copenhagen, in Helsinki during its first two years. Furthermore, this plan for the national computing center, or the building of a single computer, the ESKO, did not gain the support it needed either from the state nor the former punched card machine users, because of the politically and economically difficult situation in post-war Finnish society. In the uncertain economic year of 1956, the Finnish punched card customers of IBM decided to continue collaborating with IBM alone. Moreover, IBM also benefited by receiving expert work force educated in the Committee's computer construction project. Hopefully this Finnish case, being unsuccessful and therefore unlike other Scandinavian countries, can also assist in further comprehending the preconditions that lead to more successful developments like those in Sweden and Denmark.

Key words: Finnish Computing history, ESKO computer, Scandinavian - German cooperation, punched card use, Rolf Nevanlinna 


\section{INTRODUCTION ${ }^{1}$}

In Finland, the first, national computer construction project began in 1955 - that is concurrently with the Danish one but years later than the Swedish or the Norwegian construction. ${ }^{2}$ Unlike in other Scandinavian countries, in 1954, the Finnish project leaders had chosen to duplicate a German computer. In 1960, the construction work finally concluded with what contemporaries regarded as an out-dated machine, the ESKO. ${ }^{3}$ A contributory factor to this judgment was that in 1958, International Business Machines (IBM) imported the first (operational) computer to Finland. By this operation, IBM also claimed to be the initiator of modern computing in the country, thus competing with the national computer construction project. Consequently, IBM dominated the computer market in Finland at the end of the $1950 \mathrm{~s}$ and in the $1960 \mathrm{~s}^{4}$

A draft version of this text has earlier been presented as a paper for the session, "Computers for Scandinavian Modernization", at the annual meeting of the Society for the History of Technology in San Jose, October 2001. The paper and this article are for the most part based on my licentiate dissertation P. Paju, Ensimmäinen suomalainen tietokone ESKO ja 1950-luvun suunnitelma kansallisesta laskentakeskuksesta, [The First Finnish Computer ESKO and a 1950's Plan of a National Computing Center, in Finnish]. Licensiate Thesis, Cultural History. University of Turku, Finland 2002. The author is thankful to Anders Carlsson, Lars Heide, Hartmut Petzold, Petri Saarikoski, Hannu Salmi and Jaakko Suominen for valuable comments and suggestions.

2 H. De Geer, På väg till datasamhället. Datatekniken i politiken 1946-1963, [On the way to an information society. Information technology in politics 1946-1963, in Swedish]. Stockholm 1992, p. 17-33; L. Heide, Hulkort og EDB i Danmark 1911-1970, [Punched card machines and electronic data processing in Denmark 1911-1970, in Danish]. Århus 1996, p. 250-254; P. V. Klüver, "From Research Institute to Computer Company: Regnecentralen 1946-1964." IEEE Annals of the History of Computing, Vol, 21, No. 2, $1999,31-43$ on p. $31,33-34$. It is perhaps worth noting here that in the 1950 s there seems to have been practically no interactions with the Finnish computing people and their colleagues in Norway.

ESKO is an acronym from Electronic Serial COmputer (when spelt Finnish way) and it was a popular Finnish male name at that time.

H. Andersin \& T. Carlsson, "ESKO - ensimmäinen suomalainen tietokone, [ESKO - The First Finnish Computer, in Finnish]", in M. Tienari, ed., Tietotekniikan alkuvuodet Suomessa, [The first years of information technology in Finland, in Finnish.] Helsinki 1993, 11-23 on p. 14-15, 21-22; M. Vehviläinen, "Gender and Computing in Retrospect: The Case of Finland," IEEE Annals of the History of Computing, Vol, 21, No. 2, 1999, 4451, on p. 45; P. Paju, ESKO - tietokonetta tekemässä. Tietoteknologisen kentän muodostaminen ja nopea muutos Suomessa 1954-60 [ESKO - Making the Computer, Appropriation and Sudden Change of Computer Technology in Finland 1954-60, in Finnish]. Graduate thesis, Cultural History. University of Turku, Finland 1999, on p. 157163; J. Suominen, Sähköaivo sinuiksi, tietokone tutuksi. Tietotekniikan kulttuurihistoriaa, [Getting Familiar with the Electronic Brain, Getting to Know the Computer, in Finnish]. Publications of the Research Center for Contemporary Culture, 'No. 67. Jyväskylä 2000, 47-51, on p. 55-56. 
Some Finnish computing professionals have regarded the first computer construction as an unsuccessful effort - or dismissed it as irrelevant. Retrospectively, computing professionals have criticized the Finnish Committee for Mathematical Machines, Matematiikkakonekomitea, (established in 1954) for choosing a German computer to be copied in Finland. These computing professionals have argued that selecting a machine that used punched tape as a storage device for the program was a bad choice because even then more advanced computers had their programs stored in a memory. ${ }^{5}$

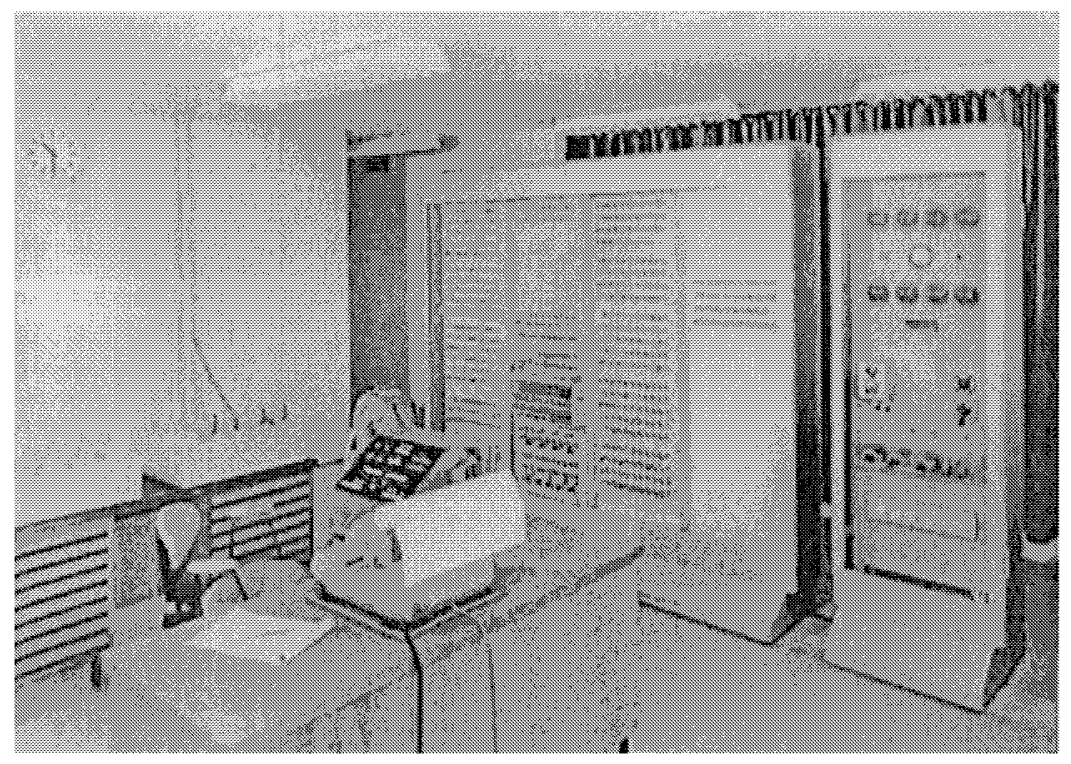

Picture 1. The ESKO computer, built in Helsinki $1955-1960$ by the Finnish Committee for Mathematical Machines, was based upon a German blueprint of a G1 a computer. The G1a in turn was based on a G1 computer designed in the beginning of the 1950s. By the end of that decade, this design was of course almost obsolete. In the ESKO the input medium was paper tape, as the computer had no internal memory for the program but a drum memory from numbers. (Courtesy of the Helsinki University Computing Center.)

So far, the history of computing has mainly been studied by computing professionals in Finland. In this article, my main argument is that their understanding of the ESKO project has been far too machine- and producer-

5 H. Andersin \& T. Carlsson, "Tyyntä myrskyn edellä, [Calm Before the Storm, in Finnish]." IBM katsaus 3/1966. 
centered. By focusing on the outcome of the ESKO project, the computing professionals have been unable to understand the other motives and plans that the members of the Finnish Committee had, beyond the building of a single computer. Studies from other Scandinavian countries, ${ }^{6}$ like Sweden and Denmark, show that the construction of early computers in those countries co-evolved with plans to establish centers for further research and education in the field of computing. ${ }^{7}$ These schemes have also been interpreted as national projects against the influence of companies like IBM. ${ }^{8}$ If successful, these Scandinavian countries would not have become merely passive adapters of computer technology, but would also have actively tried to shape new technology.

My intention is to analyze the construction of the ESKO computer mainly as a social process.' This means I will examine how the Finnish Committee for Mathematical Machines tried to build not only a technological artifact, but also social structures, and show how the interaction that resulted in turn shaped the Committee. ${ }^{10}$ I will focus on the first two years (1954-1956) of the Finnish Committee for Mathematical Machines and on the beginning of the construction of the ESKO computer. Drawing on archival material, I will describe how the Finnish group went to

6 Scandinavian countries include Denmark, Norway, Sweden and Finland.

7 H. De Geer, På väg till datasamhället, on p. 33-44; L. Heide, Hulkort og EDB i Danmark 1911-1970, on p. 211, 250-254; P. V. Klüver, "From Research Institute to Computer Company: Regnecentralen 1946-1964," on p. 31. See also J. Suominen, P. Paju \& A. Törn, "Varsinaissuomalainen linja Suomen tietoteknistymisen alkuvaiheissa. Turun laskukeskus ja Wegematic 1000 tietojenkäsittelykone, [Early Computerization in FinlandProper 1959-1964. A Study of the Beginnings of Computer Center in Turku and Wegematic 1000 Electronic Data Processing Machine, in Finnish]", Tekniikan Waiheita 18(2000): 3, 24-46.

8 James M. Nyce and Magnus Johansson in preface to Annals of the History of Computing 2/1999.

9 P. N. Edwards, "From 'Impact' to Social Process: Computers in Society and Culture" in Handbook of Science and Technology Studies. Eds. Sheila Jasanoff et al. Sage Publications 1995, (ps. 257-285); W. E. Bijker, Of Bicycles, Bakelites and Bulbs. Toward a Theory of Sociotechnical Change. Cambridge, Massachusetts, London 1995.

10 The technical details of the ESKO are therefore not central to this article. Some main features should be noted however. The ESKO was essentially an electron tube computer. It had no internal memory for the program but the program was read from paper tapes (see Picture 1, paper tapes in the background). The paper tapes also served as input media. There was also a drum memory (see Picture 1, in the middle back) for the number data. The operational speed of the ESKO was 20 additions per second. Altogether the ESKO had many special features and solutions that where tried out. For more on these, see $\mathrm{H}$. Andersin \& T. Carlsson, "ESKO - ensimmäinen suomalainen tietokone, [ESKO - The First Finnish Computer, in Finnish]"; W. Hopmann, "The G1 and the Göttingen Family of Digital Computers" in Raúl Rojas and Ulf Hashagen (eds.): The First Computers - History and Architectures. Cambridge 2000, (ps. 295-313). 
Germany to acquire a computer and why the decision to copy a German computer was not supposed to be so important a choice. ${ }^{11}$

My argument is that the aim of the Finnish Committee was more similar to its Swedish and Danish counterparts than has been previously acknowledged. I think this is because during its first two years, the Committee, adapting the model of the Swedish computing center, tried to establish a national computing center in Helsinki for the first time. ${ }^{12}$ Furthermore, I argue that it was because of the politically and economically difficult situation in post-war Finnish society that this plan for the national computing center (or the building of ESKO) did not gain the support it needed. Finnish society was in a very different situation from Swedish society that had been spared the ravages of the Second World War and was not a neighbor of the Soviet Union. In Finland in the 1950s, the state invested heavily in industrialization that was meant to provide the Finnish people with jobs and to maintain the maximum of economic independence from the Soviet Union. The economic uncertainty seems also to have influenced the punched card machine users who decided not to take risks by supporting the Finnish scientific Committee.

Finally, I argue that, despite its outcome, the ESKO project may have had a strong positive influence as an educational project in an environment not yet devoted to the problems of information technology. Not only were the first computer experts in Finland trained during this construction project, IBM Finland also responded to the competition generated by the Committee and pressure from customers, by offering the "punched card men"13 courses on new technology. Later, IBM became the largest computer supplier in the country when computers were utilized in modernizing Finnish society towards a welfare state in the 1960 s.

11 The construction project in Germany remains a subject for further research. For the German developments, see $\mathrm{H}$. Petzold, Rechnende Maschinen. Eine historische Untersuchung ihrer Herstellung und Anwendung vom Kaiserreich bis zur Bundesrepublik. Düsseldorf: VDI-Verlag, 1985; H. Petzold, Moderne Rechenkünstler. Die Industrialisierung derRechentechnik in Deutschland. München: Beck 1992; W. Hopmann, "The G1 and the Göttingen Family of Digital Computers"; H. Petzold, "Hardwaretechnologische Alternativen bei Konrad Zuse" in Hans Dieter Hellige (hrsg.): Geschichten der Informatik. Visionen, Paradigmen und Leitmotive. Springer Verlag 2003, (ps. 79-140).

12 In Denmark there also was a computing center created at the same time. See P. V. Klüver, "From Research Institute to Computer Company: Regnecentralen 1946-1964," p. 31, 3334.

13 The "punched card men" (reikäkorttimiehet) is what the Finnish punched card organisation managers called themselves. 


\section{LIMITED FUNDING IN 1954: WHY NOT A GERMAN COMPUTER?}

In the 1940s, Finland was in no position to acquire a computer of its own. Finland, at that time, was a country of four million people, located between Sweden and the USSR. She had suffered heavily from the two wars that she waged against the Soviet Union during the period of the Second World War. After the war ended, Finland was not occupied. However, it had to pay heavy war reparations to the Soviet Union. Those debts were paid off in 1952, which was also the year of the Helsinki Summer Olympic Games. During the Cold War, Finland found itself in a difficult situation, caught between the Western and the Eastern block and, simultaneously, foreign policy relations with the Soviet Union created political battles and uncertainty in the country. ${ }^{14}$

This, often unstable, political, and economic situation and the lack of tradition in science policy, prevented investment in science and technology in Finland, which was then still mostly an agrarian society. The scarce resources for scientific work in Finland led many ambitious Finnish graduates to emigrate, mostly to Sweden and the United States. We can say that there was no science policy in Finland, only the policies of some individual scientists in high positions who belonged to the Academy of Finland - so it was a very different situation from, for example, that in Sweden. ${ }^{15}$

However, at the Helsinki University of Technology, there was a Professor of Engineering Physics, Erkki Laurila (1913-1998), who had conducted research on analogue machines already in the 1930s. He was interested in the new mathematical machines after the Second World War. Despite modest funding, Laurila could observe developments in mathematical machines from journals and, not least, on trips to Sweden. Together with his engineering students, Laurila built an analogue machine in Helsinki in the beginning of the 1950 s. $^{16}$

14 For recent history of Finland in English, see O. Jussila, S. Hentilä \& J. Nevakivi, From Grand Duchy to Modern State. A Political History of Finland since 1809. Translated from Finnish by David and Eva-Kaisa Arter. London Hurst 1999.

15 The Academy of Finland was created in 1949. K-E. Michelsen, Valtio, teknologia, tutkimus. VTT ja kansallisen tutkimusjärjestelmän kehitys, [The State, Technology and Research. The Technical Research Centre of Finland and the Development of the National Research System]. Valtion teknillinen tutkimuskeskus, Espoo, Helsinki 1993, on p. 173175, 180-186; K. Immonen, Suomen Akatemia suomalaisessa tiedepolitiikassa 1970luvulla [Academy of Finland in the Finnish Politics of Science in 1970's, in Finnish]. Helsinki, Otava 1995, on p. 18-24. See also Anders Carlsson's article in this volume.

16 E. Laurila, "Stieltjesplanimetri, suomalainen integroimiskoje, [Stieltjesplanimeter, a Finnish Integration Device, in Finnish]." Teknillinen Aikakauslehti 1939; E. Laurila, 
Finally, in 1954, Laurila, with the support of the central Finnish scientific authorities in mathematics, made a proposal to the Academy of Finland to establish a committee to investigate the possibilities of having a "mathematical machine"17 available in Finland. After only a few weeks, the Finnish Committee for Mathematical Machines began its work. To ensure funding, a member of the Academy of Finland and a mathematics professor in the University of Zürich (Switzerland), the authoritative and internationally well-known Finnish mathematician Rolf Nevanlinna (18951980), became chair of the Committee, while Professor Laurila became vicechairman. The other members of the Committee were mathematicians who represented a wide array of different needs in calculation work, as well as a general who represented the military. The Committee for Mathematical Machines, in 1954, was the first scientific committee to be founded by the Academy of Finland in post-war Finland. ${ }^{18}$

The members of the Committee had many reasons for wanting a computer in the country. The most obvious reason was that a computer would be beneficial for scientific work in Finland. Some members of the Committee had already been able to use the Swedish computers for their calculations, but a computer in Helsinki would be very welcome. Professor Laurila preferred to have his engineers trained in digital computing technology so that they would be able to establish a computing center in Finland. Finally, the military wanted to calculate tables for the Ballistics Office more quickly and cheaply. ${ }^{19}$

\footnotetext{
"Mekanisoitu ja sähköistetty matematiikka, Tekniikan ja luonnontieteitten matematiikka uusilla urilla, [Mathematics Mechanized and Electrified, Mathematics of Technology and Natural Sciences in a New Direction, in Finnish]." Teknillinen Aikakauslehti 1948; P. Paju, Ensimmäinen suomalainen tietokone ESKO, pp 38-43. Professor Laurila also received an earlier version of the proposal made by a public investigation group on mathematical machines in Sweden in 1947. Betänkande med förslag till närmast erförderliga åtgärder för tillgodoseende av Sveriges behov av matematikmaskiner avgivet av matematikmaskinutredningen. Stockholm den 30 april 1947. Personal Archive of Professor Erkki Laurila. His papers are at present in the National Archives of Finland. Regarding the proposal, see Anders Carlsson's article in this volume.

${ }^{17}$ From now on I will use the term computer for brevity.

18 A Letter from Erkki Laurila to the State Board for Natural Sciences, 21.3.1954. Archive of the Academy of Finland; The Finnish Committee for Mathematical Machines, minutes of meetings 14.4.1954, founding session. 1954, Archive of the Academy of Finland; Interview with Mr. Erkki Laurila 16.12.1997; Interview with Mr. Hans Andersin 15.5.1998; O. Lehto, Korkeat maailmat. Rolf Nevanlinnan elämä, [Higher Worlds. The Life of Rolf Nevanlinna, in Finnish.] Keuruu 2001, on ps. 211-219.

19 A member of the Finnish Committee, the professor of astronomy at the University of Helsinki, Gustav Järnefelt had had his calculations concerning star models computed already in 1951. Rapport för oktober - december 1951 över arbetet inom Matematikmaskinnämndens arbetsgrupp. Matematikmaskinnämnden's Archive in the
} 
It was the chairperson, Nevanlinna, who was most active in persuading the Committee to choose a German computer. The chairman was offered the design of a computer to copy from Göttingen, Germany. ${ }^{20}$ That offer also came as a surprise to Professor Laurila. The Committee had first decided that Laurila should explore alternatives for acquiring a computer, whether to purchase or to build one. While Laurila was making his inquiries, chairperson Nevanlinna visited his old university town in West Germany, Göttingen, in the summer of 1954. Nevanlinna was very excited about the new machines but he was a theoretical mathematician who had defended his doctoral thesis much earlier (1919). It is no exaggeration to state that his knowledge of computer technology was very poor when his friends and colleagues at the Max-Planck Institut für Physik in Göttingen offered him a blueprint of their newly planned, small, scientific, digital computer, the G1a, which people could copy without charge in Finland. ${ }^{21}$

The German computer differed somewhat from what Professor Laurila thought was favorable but he had no better, that is, less expensive, suggestion. An important advantage was that the Germans planned to complete this small machine within one and a half years. It was this tight timetable that helped Laurila content himself with this German project as a learning process for his students, the engineers. ${ }^{22}$

The German alternative was by no means the only one considered, however. Professor Laurila had already sent two of his young engineers, Hans Andersin and Tage Carlsson, who both spoke Swedish as their native language, to study computing in Matematikmaskinnämnden in Stockholm. Returning from their short stay in Sweden in autumn 1954, Andersin and Carlsson were able to report to their professor that the Royal Swedish Academy of Engineering Sciences could offer the blueprints of the BESK

National Archives of Sweden, Stockholm; P. Paju, Ensimmäinen suomalainen tietokone ESKO, pp. 44-67.

20 I think Nevanlinna was offered a machine because he was already a famous mathematician in Europe in the 1920s and the German scientists in Göttingen thought this would be another way to win support and legitimate their computer constructions. Nevanlinna had also been a visiting mathematics professor in Göttingen in 1936-1937. At that time, Nevanlinna was a known Nazi-sympathiser. On this topic, see O. Lehto, Korkeat maailmat $_{2}$ on p. 139.

21 A Letter from Ludvig Biermann to H. Piloty, A. Walther and K. Küpfmüller 20.7.1954. Archive of the Max-Planck-Gesellschaft, Berlin; P. Paju, Ensimmäinen suomalainen tietokone ESKO, pp. 67-75; Interview with Mr. Erkki Laurila 16.10.1997; Nevanlinna, Muisteltua, [From My Memory, in Finnish]. Helsinki Otava 1976; on p. 194.

22 The Finnish Committee for Mathematical Machines, minutes of meetings 4/1954, 12.10.1954, Archive of the Academy of Finland; Interview with Mr. Erkki Laurila 16.10.1997. See also R. Nevanlinna, Muisteltua, [From My Memory, in Finnish], on p. 194. 
computer for free to the Finnish Committee. ${ }^{23}$ However, the Committee then calculated that to build such a large machine would be too expensive (the German alternative would cost only one fifth of the expense of the BESK). Also, they argued that there would not be enough needs and users for such an efficient computer like BESK in Finland, even in the near future. The young Finnish engineers would have preferred to copy the BESK; for them it was, of course, an up-to-date computer, but after some protests they accepted that they would copy the Göttingen computer G1a. After all, it would only take a year and a half to complete the G1a, they thought. ${ }^{24}$

We can explain in part this selection process by a gap between the generations. For scientists from Nevanlinna's generation in Finland, Germany still represented superiority in technical expertise. For more practical engineers like Professor Laurila, who knew better, this Germanmindedness was something from the past that could not be avoided in the Finland of the $1950 \mathrm{~s}^{25}$ Nevertheless, the Finns must have been impressed by the first Göttingen machine: The G1 - the only such machine operating in Germany - which had already been used successfully for two years by $1954 .^{26}$

A German constructor, Wilhelm Hopmann (1924-2002), planned to build the G1a -computer as a follow-up version to the G1 computer. ${ }^{27}$ Hopmann designed the G1a as a "minimal machine"; a construction that would need only a minimal number of parts and would still be of use to scientists from various disciplines. ${ }^{28}$ What the Finns, Nevanlinna and Laurila, did not know

${ }^{23}$ These were no doubt only preliminary discussions. The Royal Swedish Academy of Engineering Sciences, in Swedish Ingenjörsvetenskapsakademien had, according to Anders Carlsson, no formal rights to the BESK drawings. See also Anders Carlsson's article in this volume.

${ }^{24}$ Interview with Mr. Hans Andersin 15.5.1998; P. Paju, Ensimmäinen suomalainen tietokone ESKO, pp. 77-81. The Danes accepted an offer to copy the BESK construction for free and their computer DASK was ready in 1957. L. Heide, Hulkort og EDB $i$ Danmark 1911-1970, on p. 250-253, passim; P. V. Klüver, "From Research Institute to Computer Company: Regnecentralen 1946-1964.", on p. 33.

25

H. Andersin \& T. Carlsson, "ESKO - ensimmäinen suomalainen tietokone, [ESKO - The First Finnish Computer, in Finnish]", on p. 12-13; Interview with Mr. Erkki Laurila 16.10.1997.

${ }^{26}$ W. Hopmann, "The G1 and the Göttingen Family of Digital Computers," on p. 298-307, 312; H. Petzold, "Hardwaretechnologische Alternativen bei Konrad Zuse". The G1 computer was the first electronic computer to be operated in Germany, starting 1952. It was built in Max-Planck Institut für Physik in Göttingen by a group headed by Heinz Billing. The G:s are for Göttingen, home town of the institute in which they were built.

${ }^{28}$ W. Hopmann, "Zur Entwiclung der G la" in Johannes Wosnik (hrsg): Elektronische Rechenmaschinen und Informationsverarbeitung. Nachrichtentechnische fachberichte, Band 4, 1956, ps. 92-96; "W. Hopmann, "The G1 and the Göttingen Family of Digital 
when opting to copy the German G1a was that the blueprint was still under development at that time - and it would take much longer than they thought in 1954 to complete this complex minimal construction.

\section{THE COMMITTEE'S AIM: A NATIONAL COMPUTING CENTER}

The Committee's decision to build a computer in Finland cannot be understood without paying attention to the larger vision of computer use that was developing within the Committee. It seems that, right from the start in 1954, the Committee intended not only to have a computer built but also to create a national computing center in Helsinki, the capital of Finland. Especially for Professor Laurila this computing center was of particular interest. Already when the two engineers who were going to build the computer were still studying computer technology in Göttingen during the winter of 1955, Laurila wrote a letter stating that he would like to appoint one of the scholarship holders, Hans Andersin, as the manager of this future computer center. ${ }^{29}$

This plan to establish a computing center in Finland was elaborated on during the following year, 1955, after engineers began the construction work on the Finnish G1a, the ESKO, in Helsinki. The Committee wanted to take responsibility firstly, for not only the whole scientific calculating work but also for all computer calculation work in Finland, secondly for education in the new field of computing, and thirdly for research and development work in computer machinery. The Committee aimed to have customers including the state, scientists and industrialists..$^{30}$ For the scientists, whom the members of the Committee knew best, this center would have meant an enormous improvement in calculating capacity and plenty of new possibilities for research in areas that had been underdeveloped in Finland, such as the atomic research. ${ }^{31}$

The members of the Committee realized that in order to materialize this plan, they needed support from the would-be-customers of the computing center. Perhaps the most important group was the punched card men, the

Computers," on p. 298-307, 312; H. Petzold, "Hardwaretechnologische Alternativen bei Konrad Zuse".

29

A letter from Erkki Laurila to Hans Andersin \& Tage Carlsson 28.12.1954. Archive of the University of Helsinki. This choice would leave Tage Carlsson able to fully concentrate on the (more important, at that point) technical side of building this computer and future computing service.

30 A letter from the Committee secretary Hans Andersin to Rolf Nevanlinna 8.6.1955. Archive of the University of Helsinki.

31 See K-E. Michelsen, Valtio, teknologia, tutkimus, on p. 187-189. 
leaders of punched card installations in various organizations, who had formed an association (the Punched Card Association) for themselves in 1953 in order to negotiate with the largest supplier, IBM, better. ${ }^{32}$ After constructing the ESKO for half a year in Finland, and anticipating the completion of the machine the following year, the Committee decided to offer to cooperate with the punched card men.

A representative from the Finnish Committee for Mathematical Machines, Dr Kari Karhunen, ${ }^{33}$ suggested to the annual meeting of the Punched Card Association in 1955 that there should be a joint effort to create a computing center in the country. This center could then buy a large, general purpose, electronic computer there for all to use. ${ }^{34}$ What $\mathrm{Dr}$ Karhunen did not specifically mention was that in the beginning this center would probably benefit Finnish scientists most by providing them with modern calculation equipment that the universities could not afford.

For the punched card men, a computing center did not seem such an attractive idea. At least no signs of supporting this suggestion on a large scale are to be found in the journal they published - although they reported on the meeting in question at great length. ${ }^{35}$ After studying the punched card machinery they used, one can conclude that this center-like, centralized organization was not a preferred way for them to use new electronic machines - they were more eager to buy computers of their own in order to automate their punched card machine organizations. What they needed was more and faster data processing capacity that was essentially reliable for their businesses. ${ }^{36}$ It may be that the punched card men also thought that their needs were very different from those of represented by the scientific members of the Committee. Thus, the punched card men would only marginally benefit from the center. Perhaps also the fact that the ESKO, the first computer used in the computer center, would be a scientific computer

Reikäkortti, (Punched Card journal, in Finnish. A journal the Punched Card Association published.) 1/1955; M. Vehviläinen, "Gender and Computing in Retrospect: The Case of Finland," on p. 45; J. Suominen, Sähköaivo sinuiksi, tietokone tutuksi, on p. 52-56.

33 He was a mathematician and a director of a punched card installation in an insurance company.

${ }^{34}$ Uusi Suomi, [a Finnish Newspaper from Helsinki] "A Computing Center and Electronic Calculating Machice are current issues", 28.9.1955.

35 Reikäkortti, (Punched Card journal, in Finnish) "Events at the Punched Card Association", 2/1955.

36 P. Paju, Ensimmäinen suomalainen tietokone ESKO, pp. 126-140; R. Pukonen, "Automaattisen tietojenkäsittelyn ENSI-askeleet Suomessa, [The First Steps into Automatisation in Finland, in Finnish]", in M. Tienari, ed., Tietotekniikan alkuvuodet Suomessa, [The first years of information technology in Finland, in Finnish.] Helsinki 1993,182-188; J. Yates, "Early Interactions Between the Life Insurance and Computer Industries: The Prudential's Edmund C. Berkeley." IEEE Annals of the History of Computing, Vol. 19, No. 3, 1997, 60-73. 
contributed to this opinion, although most members of the scientific Committee did not want to send that message when building the ESKO. Furthermore, these parties, one mostly of business people and the other of scientists, had no tradition in cooperation.

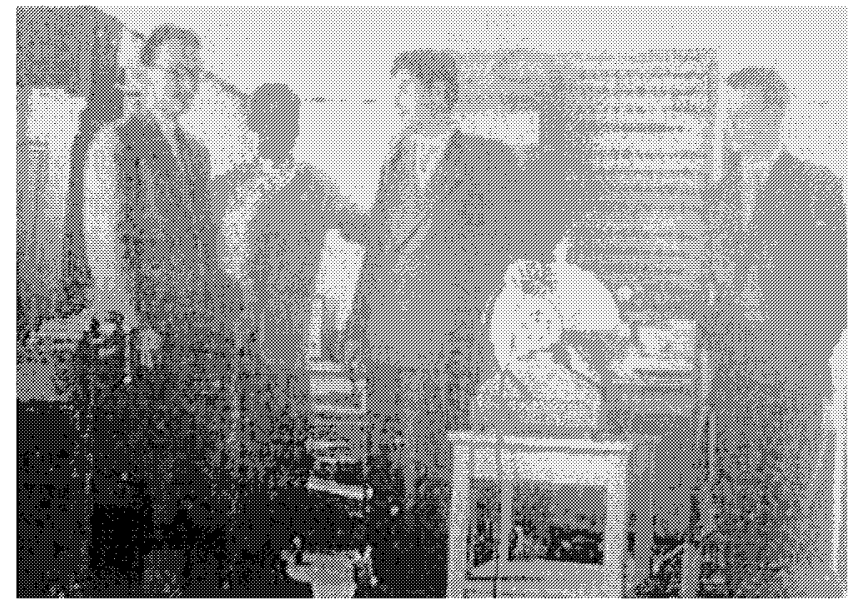

Picture 2. In summer 1956, the German constructor of the G1a, Wilhelm Hopmann (in the middle) visited Helsinki and also the laboratory where ESKO was built by (from left to right) engineer Hans Andersin, technician Veikko Jormo and engineer Tage Carlsson. At this time, the German project had already been delayed. (Courtesy of Hans Andersin.)

At the same time, IBM Finland presented the punched card men with a future option for a computer of their own, the new middle-sized computer IBM 650 . In the summer of 1955 , the company had begun marketing their Electronic Data Processing Machines to their punched card customers ${ }^{37}$ The military also did not invest its limited resources in the new and risky computer technology, but instead they purchased a punched card installation (delivered in 1955 or 1956) from IBM. ${ }^{38}$

In addition, the Committee's initiative to establish a computing center suffered a setback in early 1956 when the economic situation in the country deteriorated suddenly and dramatically. In the spring of 1956 , the country

Reikäkortti (Punched Card journal, in Finnish) "Events at the Punched Card Association", $2 / 1955$. For more on IBM in Norway at the same time, see G. Nerheim \& H. W. Nordvik, Ikke bara maskiner. Historien om IBM $i$ Norge 1935-1985, [Not just machines. History of IBM Norway 1935-1985, in Norwegian]. Oslo: Universitetsforlaget 1986.

${ }^{38}$ P. Paju, Ensimmäinen suomalainen tietokone ESKO, on p. 101. See also J. Suominen, Sähköaivo sinuiksi, tietokone tutuksi, on p. 131-132. 
faced a general strike. This crisis and the recession that followed made all prospective computer users, that is the large and growing organizations using punched card machinery, postpone their purchases. ${ }^{39}$

Why did this national computing center not receive more support from the state? The fact is that the state in Finland had made heavy investments to industrialize in the 1950s. These investments were supposed to stabilize the economy in order to maintain the country's economical independence from its neighbor, the Soviet Union. In the 1950s and 1960s, Finland was in the process of transformation from an agrarian society into an industrial one - this happened later and faster than in neighboring Sweden and other Western countries. ${ }^{40}$ The Prime Minister from the Agrarian party, Urho Kekkonen, who became President of Finland in 1956 and remained so for 25 years, had launched a program for investing in modern industries in order to increase employment among the growing population in the first half of the 1950s. A reliable source of energy was essential for industrialization. The building of large technological projects such as power plants, oil refineries and factories urgently needed public funding, but this left practically no attention or funding for the new computer technology. The ruling politicians did not see computers as helpful in their crucial effort to protect the country from growing Soviet influence, which was the hidden purpose for creating jobs for the Finnish people by industrializing the country in the 1950s. ${ }^{41}$

However, possibly the worst setback for the national computing center plan was that, in 1956, the completion date of the ESKO computer was delayed (for the first time). Building the minimal machine in Göttingen proved to be more demanding and costly than could have been imagined. In Finland, this delay in construction work also led to additional financial difficulties. Consequently, the Computing Center could not start its service. Instead, soon after the first delay, the Committee lost one of its two original employees to IBM. ${ }^{42}$

J. Auer, Hyvinvoinnin rakennuspuita. Postisäästöpankki vuosina 1886-1961, [Building Basis for the Welfare. Post-Office Bank in years 1886-1961, in Finnish]. Helsinki Postisäästöpankki 1964; Reikäkortti (Punched Card journal, in Finnish) 1/1956.

M. Vehviläinen, "Gender and Computing in Retrospect: The Case of Finland,", 45. A comparable change had taken place in other Scandinavian countries within the previous 50-80 years. Ibid.

${ }^{41}$ M. Kuisma, Kylmä sota, kuuma öljy. Neste, Suomi ja kaksi Eurooppaa 1948-1979, [Cold War, Hot Oil. Neste-company, Finland and the Two Europes 1948-1979, in Finnish]. Porvoo, Helsinki, Juva, WSOY 1997, on p. 75-106; O. Jussila, S. Hentilä \& J. Nevakivi, From Grand Duchy to Modern State.

42 The Finnish Committee for Mathematical Machines, minutes of meetings 4/1956, 5.10.1956. Archive in the University of Helsinki; H. E. Andersin, "Matematiikkakoneet konttorityössä, [The Mathematical Machines Doing Office Work]." Teknillinen Aikakauslehti 19/1956, 463-468; W. Hopmann, "The G1 and the Göttingen Family of Digital Computers"; H. Petzold, "Hardwaretechnologische Alternativen bei Konrad Zuse". 


\section{A BENEFICIAL FAILURE, AS AN EDUCATIONAL OPPORTUNITY}

In recent years, historians of technology have focused attention on failures in technological development work. For example, Graeme Gooday has noted that technological failures - and therefore also successes - have their own interpretative flexibility since technologies in themselves do not fail but are interpreted so by various people. ${ }^{43}$ This seems to be the case also with the 'failure' of the ESKO computer. Certainly, the ESKO was not completed according to schedule. It clearly did not fulfill all of the Committee members' and the engineers' expectations. However, in the context of the plans for the national computer center, the ESKO project looks different. What really failed were the Committee's plans for the center and thus their attempt to govern the development of computer technology in Finland. Nevertheless, this major failure had its positive aspects too.

The major impact of building the ESKO computer was educational: during its construction, the first computer specialists were trained in Finland ${ }^{44}$ Furthermore, Finnish IBM offered courses on the new technology to the punched card men from 1955 onwards in a response to the Committee's actions. ${ }^{45}$ These responses from IBM also continued in the economically uncertain situation in 1956 and after. This new IBM policy made the future customers for computer suppliers, the punched card men, decide to wait for the electronic data processing machines to go down in price and collaborate with IBM Finland rather than with the Committee of scientists. Under the Committee, the construction work for the ESKO computer seemed to continue for years and years.

Additionally, IBM Finland also hired the two central employees who had been working for the Finnish Committee for Mathematical Machines. These men became the first computer experts in the company and soon advanced to key positions, responsible for computer sales. ${ }^{46}$ In summation, IBM Finland, together with certain individuals, benefited most from the unsuccessful academic computer construction project in Finland. In the 1960s, IBM became the largest computer supplier in the market.

43 G. Gooday, "Re-Writing the 'Book of Blots': Critical Reflections on Histories of Technological 'Failure'". History and Technology. Vol. 14, 1998, pp. 265-291; W. P. McCray, "What Makes a Failure? Designing a New National Telescope, 1975-1984". Technology and Culture. Vol. 42, 2001, pp. 265-291.

${ }^{44} \mathrm{H}$. Andersin \& T. Carlsson, "ESKO - ensimmäinen suomalainen tietokone, [ESKO - The First Finnish Computer, in Finnish]", on p. 22.

45 Reikäkortti (Punched Card journal, in Finnish) 1-2/1956; Interview with Mr. Hans Andersin 15.5.1998.

46 Andersin, "Matematiikkakoneet konttorityössä, [The Mathematical Machines Doing Office Work]", on p. 463; P. Paju, Ensimmäinen suomalainen tietokone ESKO, on p. 230. 
Another company also received expert work force from the ESKO project. The Finnish constructor of the ESKO moved to a company named Kaapelitehdas, the Finnish Cable Works. ${ }^{47}$ The same company had started a similar computing center with the one that the scientific Committee had planned in mid-1950s. This computing center later evolved into the Electronics Department of the Nokia Company.

In sum, we can argue that in important aspects like education on the part of the scientific Committee and increased collaboration with IBM on the part of punched card machinery users, these actors from the 1950s paved the way for computers to enter Finland. This happened first at the end of 1958 (in the state-owned Post-Office Bank) and then in rapidly growing numbers during the $1960 \mathrm{~s}^{48}$

\section{CONCLUSION}

In this article, I have presented the beginnings of the first computer construction project in Finland by scrutinizing the solutions and proposals made by the Finnish Committee for Mathematical Machines in attempting to shape the new computer technology in Finland in 1954-56. Knowing the limited funds for scientific research, the Committee decided to copy a computer from Germany in 1954. This construction project was to be only the start of establishing a national computing center according to the model provided by the Swedish computing center. The Finnish punched card men, the would-be-customers for the planned computing center, however, preferred to collaborate with IBM in Finland. During the recession that began in 1956, this decision strengthened the resolve to negotiate mainly with IBM. The initiative for the computing center was left unsupported 1956 because, in addition to the above-mentioned points, the state was forced to invest in industrializing the country to maintain independence from Soviet influence. Thus, this article argues that we should not view the first Finnish computer construction only as an engineering project. Instead, we

47 The Finnish constructor of the ESKO was Tage Carlsson. A. Aaltonen, "Nokian elektroniikkateollisuuden synty: nuorten kokeilijoiden ja keksijöiden pajasta huipputeollisuudeksi. [The Birth of Electronics Industry of Nokia, in Finnish]", in M. Tienari, ed., Tietotekniikan alkuvuodet Suomessa, [The first years of information technology in Finland, in Finnish.] Helsinki 1993, 108-126, on p. 110-111.

48 For more on the first computer in Finland, an IBM 650 computer, in the Post-Office Bank, see R. Pukonen, "Automaattisen tietojenkäsittelyn ENSI-askeleet Suomessa, [The First Steps into Automatisation in Finland, in Finnish]", 182-188; P. Paju, Ensimmäinen suomalainen tietokone ESKO, pp. 229-231; M. Vehviläinen, "Gender and Computing in Retrospect: The Case of Finland," on p. 45. See also J. Suominen, Sähköaivo sinuiksi, tietokone tutuksi, on p. 53, 66-83. 
should view it within the context of a social or better socio-technical, effort to establish a national computing center by the Finnish Committee for Mathematical Machines in the mid-1950s. This wider view may help us to understand better the difficulties and outcomes of the ESKO project that ended in 1960 after construction work had faced several delays.

In addition, I suggest that we should not regard this whole ESKO project as a failure but as an important learning process in which a group of Finnish engineers started to learn and study computer technology for the first time. At the same time, it is clear that the Finnish Committee had its weaknesses (like the resources and the material linkage to Germany) and it failed to gain support and to establish a computing center. Overall, the Finnish IBM mastered the change from punched card machines to computer technology far better than the scientific committee did. In this change, as I have demonstrated, the punched card men played a significant role by preferring to collaborate with IBM. Thus, this case reinforces the importance of studying the roles that users play in the process of shaping technology in a society.

Moreover, this view of the social construction of computer technology and the interactions of these different actors in shaping of that technology informs us about the modernization process in post-war Finland. It seems that modernization mostly meant industrialization and it was not until the 1960s that computers became a key element in the modernization of Finnish society and the building of the welfare state structures. Thus, we should analyze the differences in modernization between Finland, on the one hand, and Sweden and Denmark, on the other, by comparing early computer projects in these countries. 